\title{
The socioeconomic cost of illicit drug consumption in Chile
}

\author{
Matias Fernández $H$.
}

ABSTRACT

This article estimates the magnitude of monetary resources which Chile loses or forgoes owing to the trafficking and consumption of illicit drugs. On the basis of a "cost-of-illness" methodology, it is estimated that in 2006 drug consumption in Chile represented an economic burden of 266.744 billion pesos - or US\$ 503 million in current prices that year - equivalent to $0.45 \%$ of gross domestic product (gdp) and a per capita cost of 16,232 Chilean pesos or US\$31. The bulk of this sum is related to law enforcement for drug crime or other related offences (47\%) and productivity losses reflected in the burden of disability-adjusted life years (46\%). 


\section{I}

\section{Introduction}

This article estimates the socioeconomic costs of drug trafficking and consumption in Chile in 2006 -including the costs of prevention and health care, productivity losses and law enforcement- in order to allocate a monetary value to the negative externalities caused by illegal drugs in Chile.

A sound indicator of the socioeconomic costs of drug use and trafficking is needed in order to properly substantiate and justify public decisions and actions aimed at reducing the impacts of drugs. Single and others (2003) specify four purposes for this type of study:

(i) economic estimates help argue for prioritizing drugs policies on the public agenda;

(ii) high-quality estimates provide a standard against which intervention needs can be weighed. Without such a standard, there will be a tendency for advocates for each social problem to overbid;

(iii) cost estimates help to target priority areas for action and identify failings in national reporting systems, and turn a spotlight on specific needs for improvement in national statistical systems; and

(iv) the development of improved estimates provides baseline measures to determine the efficacy of drug policies and programmes.

\section{A. Background}

Developing a good indicator of the socioeconomic costs of illicit drug consumption has become a priority and a challenge in the past decade, especially in developing countries with high consumption rates (Pacula and others, 2009). However, few countries have managed to develop quality estimates and the methodologies used vary widely. Studies conducted in the United States (Office of National Drug Control Policy, 2004), Canada (Rehm and others, 2006) and Australia (Collins and Lapsley, 2008) are probably the most advanced in the field, although estimates of a high standard have also been conducted in France (Kopp and Philippe, 2006), Spain (García-Altés, Ollé and Colom, 2002)

This article forms part of the research conducted by the group Núcleo Científico Milenio de Investigación Socioeconómica en Uso y Abuso de Drogas, financed by the Ministry of Social Development (formerly MIDEPLAN). The author is grateful for assistance provided by Pilar Larroulet, Carlos Rodríguez and Eduardo Valenzuela. and England and Wales (Godfrey and others, 2002). In Latin America, the Inter-American Drug Abuse Control Commission (CICAD) of the Organization of American States (OAS) has spearheaded the "Program to Estimate the Human, Social and Economic Costs of Drugs in the Americas", aiming to promote this kind of research in the region. This has yielded cost estimates for Argentina, Barbados, Chile, Costa Rica, El Salvador, Mexico, Peru and Uruguay. The findings of these studies are highly uneven, however, owing to over-use of secondary sources, failure to distinguish between costs related to alcohol and those related to illicit drugs - grouped in the category "psychoactive substances" - and the lack of proper estimates of indirect costs. Not all the studies have these problems to the same degree, but the estimates produced are not of the highest standard. The failure to distinguish between legal and illegal substances is a basic problem these studies share and one which - as we will argue- means that they fall short of international studies.

\section{B. What is a study of the socioeconomic costs of illicit drug use?}

Studies of the socioeconomic costs of trafficking and use of illicit drugs are based on a "cost-of-illness" (COI) methodology, which compares a real scenario in which specific disease (in this case, trafficking and consumption of drugs) and its consequences exist, with a counterfactual scenario in which the disease does not exist (Kopp, 2001). This difference is quantified in monetary terms. What is being estimated is thus the magnitude of the costs to the country of illicit drug consumption, which would not exist in the absence of the "illness".

Underlying this approach is the idea of opportunity cost, i.e. the cost incurred by investing resources in a particular activity (or an illness, in the COI approach), which could have been used for other available activities (Rehm and others, 2006). A cor study, then, quantifies the total reduction in the production of goods and services which can be attributed to the development of an illness (Kopp, 2001, page 26).

A cor estimate should not be confused with: (i) an avoidable cost study, (ii) a budgetary impact study, or (iii) a cost-benefit analysis. In the first place, unlike an avoidable cost study, a cor calculation does 
not attempt to quantify the economic resources which could "really" be saved through effective programmes and public policy. Whereas an avoidable cost study attempts to calculate the difference between the actual situation and a hypothetical situation that assumes a feasible success rate for a given policy, a cOI approach contrasts the actual situation with one in which illicit drug consumption does not exist now and never has (Segel, 2006). Second, COI calculations measure the impacts of the illness not on the public budget, but on society as a whole, including items which transcend related public spending. Lastly, unlike a cost-benefit analysis, COI estimations do not quantify the possible benefits associated with drug consumption. Whereas a cost-benefit analysis asks what would happen if the costs associated with a particular behaviour were to cease from today, a COI estimation compares the reality with a counterfactual scenario in which consumption had never started (Single and others, 2003, pp. 21 and 22). Even if a particular behaviour, like drug consumption, were to stop instantly, the consequences of past consumption would remain: they constitute "unavoidable" costs and are thus excluded from cost-benefit analysis (Single and others, 2003, p. 22). Conversely, COI studies can contribute to cost-benefit analysis.

\section{Limitations}

Estimating the costs of illicit drug consumption, however useful, has many limitations and falls far short of capturing the true magnitude of the problem. The estimation results and methods show a quantification which is apparently precise but should be treated with caution. First, the accuracy of cost studies depends on information which even the developed countries are not producing comprehensively. Hence the frequent use of secondary data and proxy approaches to the problem, which make the findings somewhat uncertain even when they operate on reasonable, duly substantiated assumptions.

A second limitation is the lack of systemic studies on the indirect impacts of drug consumption on other cost-generating behaviours or diseases. In Chile there is an estimation of etiologic (or attributable) fractions ${ }^{1}$ for drug-related crime (Valenzuela and Larroulet, 2010), and a very precarious estimation of disability-

\footnotetext{
${ }^{1}$ An etiologic fraction is the proportion of cases in which an "illness" (involvement in crime, in this case) can be attributed to exposure to a given risk factor (consumption of drugs).
}

adjusted life years (DALYs) where drugs are a risk factor in diseases other than addiction (School of Medicine, 2008). However, no etiologic fraction has been estimated for health (for evaluating the cost of treating diseases attributable partially to drug consumption) or for road traffic accidents.

Both points signal a major "external" limitation: despite our best efforts to generate a unified methodology for estimating COI for drug consumption — such as the notable work of Single and his colleagues at the Canadian Centre on Substance Abuse between 1994 and 2001- the research must ultimately settle for the information available in each country. The findings thus have differences that preclude comparisons (Pacula and others, 2009).

However, a methodology needs to be properly defined if it is to be used to conduct comparisons over time, and to evaluate at least how total costs and each cost item have evolved. The present estimate represents considerable progress in this respect: it has yielded quite accurate results for productivity losses and the costs of law enforcement for drug offences and drug-related crime, two of the most substantial items in total costs. The greatest failing, however, lies in the drastic underestimation of the direct costs of drug consumption on health and in the lack of any estimate at all of indirect health-related costs. Accordingly, the costs estimated need to be scaled up; they should serve as a starting point or floor level for future research that could remedy this shortfall.

The estimates should ideally have been based on a more recent period, since changes in consumption patterns or in the institutional context - such as the enforcement of the juvenile criminal responsibility act or the restructuring of the drug prevention agencycould have altered the total cost of drug consumption in Chile in the past few years. However, the information for an older period is often more consolidated than for recent periods. Moreover, many prestigious international estimates operate with a similar lag, with the exception of England and Wales (Godfrey and others, 2002), where the lag is just two years, and Australia (Collins and Lapsley, 2008), where it is three.

Notwithstanding their acknowledged shortcomings, the findings represent significant progress with respect to previous estimates by the National Drug Control Council (CONACE) (2005) and Olavarría (2009). This article owes much to the Olavarría study. In addition, the estimates for enforcement are far from comparable to international estimates published so far. 


\section{II}

\section{Basic methodological definitions}

The definition of social costs used in cor studies differs from that commonly used in economics: whereas social costs usually refer to the total sum of costs associated with a particular behaviour or decision, here social cost refers to what is often termed an "externality", a concept which implies the total exclusion of private costs. The resources consumers spend in the drug market are not considered social costs. Social costs refer instead to the socioeconomic burden imposed "on" society as a whole by individual agents whose consumption decisions do not factor in these consequences (Single and others, 2003, p. 14). Private costs do not generate State interventions because: (i) they originate in an entirely voluntary determination by the individuals making the decision to assume these costs (OAS/CICAD, 2006, p. 18), and are offset by individual benefits of at least the same magnitude; and (ii) insofar as they do not affect third parties, what is beneficial for the individual is assumed to be beneficial for society overall. In addition, drug spending by one agent represents income for another. This differentiation is one of the key aspects in which this article differs from Olavarría (2009).

The estimate involves no great conceptual difficulties. Structurally, it has three steps (Single and others, 2003, p. 14; OAS/CICAD, 2006):

- Identification of the adverse impacts of drug abuse.

- Documentation and quantification of the degree of causality between the abuse and the adverse impacts.

- Assignment of costs to the adverse impacts.

The first step is, in principle, fairly well agreed upon. The only aspect on which agreement is lacking is whether to include or exclude intangible costs, i.e. the emotional and physical burden (addiction, premature mortality, or fear of crime and victimization), which may be borne by drug users themselves or by people around them (Pacula and others, 2009, p. 6). Although these costs could represent a large share of the total burden of drug consumption, ${ }^{2}$ they are extremely hard to quantify (Kopp, 2001, p. 17; Segel, 2006, p. 4; Single and others, 2003 , p. 27) and measures are far from standardized.

2 Collins and Lapsley (2008) estimate that the intangible costs of drug consumption represent $45 \%$ of total socioeconomic costs in Australia in 2004 and 2005.
For these reasons, only Collins and Lapsey (2008) have incorporated them properly into the study of illicit drug costs. The instruments for this sort of analysis are not available in Chile.

The second step is more controversial. Initially, it distinguishes between direct and indirect costs: direct costs are those in which $100 \%$ causality can be established a priori (e.g. the direct costs incurred by treating addiction); indirect costs are those where imputation is partial and requires duly substantiated etiologic fractions to quantify the impact of the consumption of each drug on cost-generating behaviours or situations. In Chile, rigorous etiologic fractions for indirect costs are available only for law enforcement, i.e. the percentage of crime committed as a result of the use and trafficking of illicit drugs, and not only under their influence. Estimates, albeit less precise, also exist for indirect costs of drug consumption under the item of productivity losses, arising either from imprisonment or loss of healthy life years (DALYS).

However, there are no etiologic fractions to quantify the impacts of drug consumption on diseases other than addiction, which would help to determine what consumption costs the health system through derived and partially attributable illnesses. The lack of estimates for this item is probably the greatest defect of the calculations presented here. This article also excludes the cost of damage to property resulting from road traffic accidents, since no studies exist on etiologic fractions in this area. Unlike Olavarría (2009), ${ }^{3}$ here we have preferred to maintain a conservative stance in the estimates.

With regard to the third and last step, fairly high quality information was available for most of the items in this work, and duly substantiated estimates in cases where no direct data exist. The sources and allocation methods are set forth for each item.

\footnotetext{
3 Olavarría's procedure imputes to drugs the full cost generated by road traffic accidents where an illicit substance was detected. This is not adequately substantiated and overstates the measurement. As Longo and others (2000a and 2000b) show, the responsibility rate in road traffic accidents varies widely by type of drug and may even reflect an inverse correlation for drivers with low blood concentrations of tetrahydrocannabinol (THC).
} 


\section{Cost structure}

The costs considered in the study were grouped into direct and indirect costs for four items:

i. Prevention: includes campaigns, money provided for drug research and the entire budget of the National Drug Control Council (CONACE) ${ }^{4}$ not corresponding to these areas or to rehabilitation.

${ }^{4}$ In February 2011 CONACE was refounded as the National Service for Drug and Alcohol Consumption Prevention and Rehabilitation (SENDA). ii. Health: treatment in the public system for drug consumption. The private system and indirect costs are excluded owing to lack of information and of studies on etiologic fractions.

iii. Productivity losses: the opportunity costs of DALYs attributable to mortality and morbidity resulting from drug addition, the drug-attributable risk of other diseases, and imprisonment for crimes directly and indirectly related to drugs.

iv. Enforcement: resources used to prosecute crime and infringements of the drugs law and crimes and infractions committed because of drugs (see table 1).

TABLE 1

\section{Cost structure}

\begin{tabular}{|c|c|c|}
\hline & Direct costs & Indirect costs \\
\hline Prevention & $\begin{array}{l}\text { CONACE } \\
\text { Other institutions }\end{array}$ & - \\
\hline Health (public) & $\begin{array}{l}\text { Primary and hospital care } \\
\text { CONACE partners } \\
\text { Other institutions }\end{array}$ & (No etiologic fractions) \\
\hline Productivity losses & $\begin{array}{l}\text { Imprisonment for offences against drugs } \\
\text { law } \\
\text { Addiction-related mortality and morbidity }\end{array}$ & $\begin{array}{l}\text { Imprisonment for partially attributable crimes } \\
\text { Mortality and morbidity partially attributable to drug } \\
\text { consumption (where drugs are a risk factor) }\end{array}$ \\
\hline $\begin{array}{l}\text { Enforcement } \\
\text { (Each subitem for adults and } \\
\text { juveniles separately) }\end{array}$ & $\begin{array}{l}\text { Offences against drugs law: } \\
\text { Police system } \\
\text { Judicial system } \\
\text { Penal system / SENAME } \\
\text { Other institutions }\end{array}$ & $\begin{array}{l}\text { Enforcement costs for partially attributable crimes: } \\
\text { Police system } \\
\text { Judicial system } \\
\text { Penal system / SENAME }\end{array}$ \\
\hline
\end{tabular}

Source: prepared by the author.

CONACE: National Drug Control Council.

SENAME: National Children's Service.

\section{III}

\section{Results}

\section{A. General findings}

As illustrated in tables 2 and 3, in 2006 drug consumption in Chile represented an economic burden of at least 266.744 billion Chilean pesos (CLP) at that year's prices (or 318.681 billion pesos in today's terms, at 30 April 2011). This is equivalent to over US\$ 503 million (in average nominal terms for 2006), and represented $0.45 \%$ of GDP that year, and a per capita cost of CLP 16,233 or US\$ 31 (see tables 2 and 3).

The largest portion of these costs $(47 \%)$ was expended on law enforcement in relation to crimes committed either against the drugs law or because of drugs (to obtain them, in the case of addicts; under their influence, where the individual would not have committed the crime otherwise; or in the drugs market). 
Estimated socioeconomic costs of drug consumption in Chile: total and by item, 2003 and 2006

(Millions of nominal pesos, thousands of dollars and percentages)

\begin{tabular}{|c|c|c|c|c|c|c|}
\hline & \multicolumn{3}{|c|}{2003} & \multicolumn{3}{|c|}{2006} \\
\hline & $\begin{array}{l}\text { Millions } \\
\text { of pesos }\end{array}$ & $\begin{array}{l}\text { Thousands } \\
\text { of dollars }\end{array}$ & Percentages & $\begin{array}{l}\text { Millions } \\
\text { of pesos }\end{array}$ & $\begin{array}{l}\text { Thousands } \\
\text { of dollars }\end{array}$ & Percentages \\
\hline Prevention & 9103 & 13166 & 11.6 & 13070 & 24647 & 4.9 \\
\hline Public health & 12625 & 18260 & 16.0 & 5093 & 9605 & 1.9 \\
\hline Productivity losses & 18187 & 26305 & 23.1 & 122293 & 230620 & 45.9 \\
\hline Enforcement & 38852 & 56193 & 49.3 & 126288 & 238154 & 47.3 \\
\hline Total & 78767 & 113924 & 100 & 266744 & 503026 & 100 \\
\hline Nominal at 30 April 2011 & 101503 & 220.4 & 100 & 318681 & 692.0 & 100 \\
\hline
\end{tabular}

Source: prepared by the author on the basis of data for 2003 from the National Drug Control Council (CONACE), Estudio de costos asociados al consumo y tráfico de SPA ilegales en Chile para el año 2003, Santiago, Chile, 2005.

TABLE 3

Estimates of socioeconomic cost of drug consumption: overall results, 2003 and 2006

\begin{tabular}{lrr}
\hline & 2003 & 2006 \\
\hline Cost of drug consumption in & & \\
millions of pesos & 78767 & 266744 \\
Percentage of GDP & 0.15 & 0.45 \\
Per capita cost in pesos & 4948 & 16233 \\
Per capita cost in dollars & 7.2 & 30.6 \\
\hline
\end{tabular}

Source: prepared by the author on the basis of data for 2003 from the National Drug Control Council (CONACE), Estudio de costos asociados al consumo y tráfico de SPA ilegales en Chile para el año 2003, Santiago, Chile, 2005.

GDP: gross domestic product.

The next largest cost is productivity losses, at $46 \%$ of the total. Together, these two items represent $93 \%$ of the total socioeconomic costs of drugs in Chile, although this proportion is over-estimated owing to the underestimation of health costs, which inflates the relative proportion of the other items. Prevention costs represent $5 \%$ of the total, and public health costs, $2 \%$.

The study for 2003 (CONACE, 2005) found a very different cost distribution: in this case, too, the largest share was represented by enforcement - an even larger percentage than we find - and the second largest by productivity losses $(23 \%)$. The CONACE study heavily over-estimated for enforcement, because crimes were imputed to drug consumption merely by possession (no etiologic fractions were used), and heavily underestimated for productivity losses owing to failings in the data sources used. This article corrects that failing by using a study by the School of Medicine (2008) on disease burden and attributable burden to arrive at a more accurate estimate of the economic burden of drug addiction and drug consumption.

The third item, public health, represented $16 \%$ of total costs: the greater magnitude in this case reflects the fact that the estimates were conducted on the basis of secondary sources which yielded different results from the budgetary information on which the present work is based, as well as the inclusion of indirect costs on the basis of a study on drug consumption in emergency room patients "Estudio de consumo de drogas en consultantes de los servicios de urgencia" (CONACE/CIGES, 2001). However, the drug-attributable fractions in that study were estimated as a percentage of total admissions for external causes in which the presence of drugs was detected by a urine test. Again, this means attributing to drug use the whole set of incidents in which they are detected; for example, drugs were treated as the sole cause in all accidents in which they were found to be present. As we have argued, this procedure is highly questionable: if drugs explain 100\% of the accident, it is then impossible to explain accidents in which no drugs were detected. The lack of any study that provides reliable etiologic fractions is the reason why this estimate does not include indirect costs under the public health item, notwithstanding that this means leaving out a particularly significant item.

Fourth and last, this article finds that prevention represents $11.6 \%$ of total costs, more than in the 2006 study. This is explained by the smaller volume of total costs, since the absolute value of this item rose considerably (from US\$13.2 million in 2003 to US\$ 24.7 million in 2006). But, since the sources and methodologies used differ significantly, this comparison is merely illustrative and does not reflect actual changes. 


\section{B. Estimates of the socioeconomic costs of drug consumption by item}

\section{Prevention}

As shown in table 4, in 2006 prevention costs amounted to CLP 13.07 billion, funded mostly from the budget of the National Drug Control Council (CONACE). What is now the National Service for Drug and Alcohol Prevention and Rehabilitation (SENDA, formerly CONACE) finances most of the work of drug consumption prevention in Chile. Its priority activity "SENDA Previene" (formerly a CONACE programme entitled "Previene") receives an additional autonomous contribution from the municipal government for local implementation. CONACE also makes transfers to regional and subregional governments and - for research purposes - to the United Nations Development Programme (UNDP), the National Children's Service (SENAME) and other community agencies, such as foundations, churches and private non-profit corporations. The largest cost — which is, however, indirectly linked to prevention- is "other CONACE costs", which is the sum of all CONACE costs other than those listed above and of transfers for rehabilitation, including under public health costs. These other costs correspond mainly to the Council's national level administrative costs. They are included under this item because the Council's ultimate aim is prevention and in the absence of drug consumption (the counterfactual scenario), it would not exist at all. Lastly, the investigative branch of the Chilean police force, Policía de Investigaciones de Chile (PDI), makes a small contribution through its Department of Antinarcotics Education and Public Safety for workshops on preventing drug consumption.

\section{Public health}

Public health usually represents a high portion of total costs in international cor studies. By contrast, here the costs to the public health system of the use and abuse of illicit drugs are grossly underestimated. Not only are indirect costs not counted - since there is no study on drug-attributable fractions for related diseases in Chile - but the direct costs are underestimated as well because of the lack of information on private health care and treatment for addiction.

Olavarría (2009) attempted to estimate private health costs attributable to drugs. He calculated the total number of treatments conducted in Chile using the expanded database of the CONACE study of the general population for 2006, assigning each treatment the corresponding public system value and subtracting from that sum the known total cost of treatments paid for out of public funds. It is thus assumed that the cost of private health treatment is given by subtracting known costs from the total costs estimated using the survey. Theoretically this exercise is reasonable, and since it does not separate drug and alcohol costs, the estimate is apparently plausible.

However, when, in this procedure, the drug-related costs are separated from alcohol-related costs, the results become so nonsensical that negative costs are found for certain types of treatment; for example, there are cases

TABLE 4

Prevention costs, 2006

(Millions of pesos in nominal terms)

\begin{tabular}{llr}
\hline Prevention - CONACE & CONACE en su comuna: "Previene" & 2681 \\
& CONACE transfers to regional governments & 2049 \\
& CONACE transfers to provincial governments & 96 \\
& CONACE transfers to community organizations & 21 \\
& CONACE transfers to UNDP & 149 \\
& CONACE - SENAME agreement & 710 \\
& CONACE transfers to other agencies & 5965 \\
\hline Prevention - other institutions & Other CONACE costs (not including rehabilitation) & 14 \\
& PDI workshops & 683 \\
Total & Municipalities (independent contributions to Previene scheme) & 13070
\end{tabular}

Source: prepared by the author on the basis of data for 2003 from the National Drug Control Council (CONACE), Estudio de costos asociados al consumo y tráfico de SPA ilegales en Chile para el año 2003, Santiago, Chile, 2005

CONACE: National Drug Control Council.

SENAME: National Children's Service.

UNDP: United Nations Development Programme.

PDI: Chilean police force investigative branch. 
in which the public system (known number) registers more treatments than the total estimated number arising from the survey (which should correspond, in Olavarría's strategy, to the sum of public and private treatments). This absurd finding highlights the risk of generalizing by extrapolating a very small number of cases to the national level, and provides conclusive grounds for excluding this item for lack of information.

In public health, Chile does not have direct sources of information on the costs of primary and hospital care attributable exclusively to illicit drugs; in the health system the two types of treatment - for drugs and alcohol - come under a single budget item. The costs linked to each of these two problems can, however, be estimated relatively accurately from the proportion of hospital bed occupancy for each, according to records of the Health Data and Statistics Department (DEIS) for 2006. Tables 5 and 6 show the data used to perform this calculation.

Although alcohol-related hospital stays represent $75.5 \%$ of total stays in relation to both substances, the duration of drug-attributable stays is considerably longer, with an average of 19.4 days per patient, far more than

TABLE 5

Hospital stays and hospital bed occupancy days due to drugs and alcohol, 2006

\begin{tabular}{lrr}
\hline & Alcohol & Drugs \\
\hline Total stays & 7530 & 2447 \\
Total hospital bed occupancy days & 69683 & 47441 \\
Average hospital bed occupancy days & 9.3 & 19.4 \\
Percentage of total stays & 0.5 & 0.1 \\
Percentage of total hospital bed & & 0.52 \\
occupancy days & 0.77 & 0.52 \\
\hline
\end{tabular}

Source: prepared by the author on the basis of data on hospital stays from the Department of Health Statistics and Information (DEIS) of the Ministry of Health of Chile.

TABLE 6

\section{Hospital stays and days of hospital bed occupancy due to drugs and alcohol as a percentage of total for alcohol + drugs, 2006}

Drug-related stays as \% of stays related to both alcohol and drugs

Alcohol-related stays as \% of stays related to both alcohol and drugs

Drug-related hospital bed occupancy as \% of occupancy related to both alcohol and drugs

Alcohol-related hospital bed occupancy as \% of occupancy related to both alcohol and drugs

Source: prepared by the author on the basis of data on hospital stays from the Department of Health Statistics and Information (DEIS) of the Ministry of Health of Chile. the average 9.3 days stay in alcohol-attributable cases. Thus, the public system covered 69,683 days of hospital bed occupancy for alcohol and 47,441 for illicit drugs. These figures may be used to estimate costs: days of hospital bed occupancy for drugs represent $40.5 \%$ of the days of total occupancy for both alcohol and drugs and the same percentage of resources allocated for both items. Accordingly, we have assumed that $40.5 \%$ of the resources allocated to alcohol and drugs in hospital care corresponds to drugs and 59.5\% to alcohol. Since the budgets show that total resources allocated to hospital treatment for alcohol and drugs was CLP 1.062 billion, $40.5 \%$ of that sum, i.e. CLP 430.4 million, was spent on drug-attributable cases.

In the absence of data on treatment in primary care facilities and psychiatric hospitals, we have assumed that the resources allocated to alcohol and drugs are distributed similarly to the proportions seen in the general hospital data. Estimates performed by Olavarría (2009) indicate that the costs for both alcohol- and drug-related treatment amount to CLP 2.195 billion, of which drug-attributable treatment would represent $40.5 \%$, or CLP 889 million.

In addition, both the estimate for 2003 (CONACE, 2005) and the Olavarría study (2009) on alcohol and drugs in 2006 include treatment spending by non-governmental organizations (NGOS); the CONACE study includes only one organization, however, while Olavarría's work includes the amounts spent by nine NGOs, all in the Metropolitan Region, which responded to the author's request for information. Given that data on NGO treatment spending are not compiled systematically, this article has excluded them on the basis that a cost study must be based on a stable model that can be replicated over time; the random selection of these institutions makes it impossible to include them in a systematic and comparable study. A comprehensive register of NGOs working on drug rehabilitation with high quality data would be needed in order to overcome this problem.

Conversely, the costs of rehabilitation and detoxification treatment in prisons and SENAME centres are well documented and, probably as a result, constitute the main item in public health costs. It may be assumed that the costs of treatment in private centres are considerable, but there is no information in this respect (see table 7).

\section{Productivity losses}

Costs from productivity losses are often the largest item within the estimated socioeconomic costs of drugs. In the United States, they represented $71.2 \%$ of all socioeconomic costs attributed to drug consumption for 
TABLE 7

Public health costs linked to drug consumption and abuse, 2006

(Millions of nominal pesos)

Subitem

Treatment for psychoactive substances in primary health facilities

Treatment in general and psychiatric hospitals

FONASA - CONACE agreement

CONACE - GENCHI agreement

Contributions from GENCHI

Other institutions

Total

Source: prepared by the author on the basis of data for 2003 from the National Drug Control Council (CONACE), Estudio de costos asociados al consumo y tráfico de SPA ilegales en Chile para el año 2003, Santiago, Chile, 2005, Olavarría y Asociados, 2009, and data from the Department of Health Statistics and Information (DEIS) of the Ministry of Health of Chile.

CONACE: National Drug Control Council.

FONASA: National Health Fund.

GENCHI: Gendarmería (prison guard service) of Chile.

2002 (Office of National Drug Control Policy, 2004). The present cost estimation works initially with two categories under this item: (i) costs for disability-adjusted life years (DALYs) through illness or premature death, and the costs for life years lost through imprisonment, and (ii) direct and indirect costs.

\section{(a) Productivity losses from incarceration: direct and indirect costs}

Costs from incarceration for offences against drug laws are obtained from the product of the average number of inmates imprisoned for infringements of drug law, the minimum monthly wage - CLP 131,250 in 2006and a 12-month period. The assumption here is that the minimum wage is a more realistic alternative $\operatorname{cost}^{5}$ for the adult prison population and the average income for the population generally.

Calculating the costs of imprisonment for crimes partly attributable to drugs is rather more difficult. First of all, Chile does not record precise information on the average number of inmates for each type of crime. The only information available is the distribution of crimes among the prison population. On the basis of that information, a good estimate may be obtained by comparing the proportion imprisoned for drug offences. Of the average numbers of inmates in closed prisons, in 20063,468 of a total of 38,007 , i.e. $9.13 \%$, were

\footnotetext{
5 Olavarría (2009) uses another source and considers only convicted inmates. Here the figure for total inmates is used, because those charged, on trial and convicted all represent a cost directly associated with drug consumption.
}

imprisoned for drug offences. At the same time, the data available on inmates' crimes shows that of a total of 139,333 crimes, 12,487 , or $8.96 \%$, were drug-related. ${ }^{6}$ Since the two percentages are almost identical, for the purposes of calculating the average number imprisoned each year for drug offences, we assume the percentage estimated on the basis of the prison population's total crimes to be equal to the average percentage imprisoned for those crimes each year. We always use a 12-month period, because the estimate of the average numbers imprisoned for each crime is precisely calculated and a productivity cost may be assigned for each of the 12 months. What is not known, however, is the duration of imprisonment of each individual by type of crime and imprisonment status (detained, on trial or convicted). The result of this estimate is shown in the column "average prisoners 2006" in table 8.

Secondly, estimates of productivity losses from crimes attributable to use, abuse and traffic of drugs which are not, however, typified as offences against the drugs law require an estimate of etiologic fractions which in Chile has recently been developed by Valenzuela and Larroulet (2010). In epidemiology, an etiologic or attributable fraction is a form of indirect quantification of morbidity and mortality due to a specified risk factor (Ridolfo and Stevenson, 2001, p. 2). In this case, the fraction corresponds to the proportion of various types of crime that may be attributed to the consumption of or addiction to different drugs.

\footnotetext{
${ }^{6}$ Crimes and not people: many inmates are in prison for more than one crime.
} 


\begin{tabular}{|c|c|c|c|c|c|}
\hline & & $\begin{array}{c}\text { Average } \\
\text { prisoners } \\
2006^{\mathrm{a}}\end{array}$ & $\begin{array}{l}\text { Attributable } \\
\text { fraction }^{\mathrm{b}}\end{array}$ & $\begin{array}{l}\text { Minimum } \\
\text { wage }^{c} \\
\text { in pesos }\end{array}$ & $\begin{array}{l}\text { Cost in } \\
\text { millions } \\
\text { of pesos }\end{array}$ \\
\hline \multicolumn{2}{|c|}{ Imprisonment for offences against drugs law (direct cost) } & 3468 & 1 & 131250 & 5462 \\
\hline \multirow[t]{4}{*}{ Imprisonment for related crime (indirect costs) } & Theft & 14601 & 0.327 & 131250 & 7520 \\
\hline & Violent theft & 7906 & 0.287 & 131250 & 3574 \\
\hline & Sexual crime & 1447 & 0.079 & 131250 & 180 \\
\hline & Homicide & 1939 & 0.206 & 131250 & 629 \\
\hline \multicolumn{2}{|l|}{ Total } & & & & 17365 \\
\hline
\end{tabular}

Source: prepared by the author on the basis of:

a Ministry of Justice, Compendio estadístico de la población atendida por Gendarmería de Chile, Santiago, Chile, Gendarmería de Chile, Sub Departamento de Estadística y Control Penitenciario, 2006.

b E. Valenzuela and P. Larroulet, "La relación droga y delito: una estimación de la fracción atribuible", Estudios públicos, No. 119, Santiago, Chile, Centro de Estudios Públicos (CEP), 2010.

c Act No. 20.039 on the minimum monthly wage.

Valenzuela and Larroulet (2010) use the tripartite model by Goldstein (1985) to assess this link. In this model, the impact of drug consumption on the commission of crime occurs in three scenarios:

i. A "psycho-pharmacological" connection is said to exist where crimes are committed under the influence of substances that increase excitability, irrationality or disposition to violence, including cases in which the victim is under the effects of a particular substance, on the understanding that a victim's vulnerability can constitute an opportunity to commit a crime.

ii. A "compulsive economic" link is said to exist where the drug addict commits a crime in an attempt to obtain drugs or the means necessary to obtain them; and lastly,

iii. A "systemic" link exists in those crimes that arise from the operation of drug production and exchange networks. Based on this conceptualization etiologic fractions are estimated for each type of crime and connection, on the basis of studies by SENAME on the committing population (SENAME, 2006) and by CONACE on the adult prison population in 2007 (CONACE, 2007).

Lastly, the minimum wage is used for the income factor rather than the average wage, on the basis that the minimum wage is a more realistic alternative cost in the case of the imprisoned population (see table 8). (b) Productivity losses from drug-attributable morbidity and mortality: disability adjusted life years (dalys)

- Study of disease burden and attributable burden in Chile

Losses through morbidity and mortality are a particularly important item in international studies. For Chile, the Public Health Department of the School of Medicine at the Catholic University of Chile (School of Medicine, 2008) estimated DALYs as a "disease burden", i.e. specifically owing to an disease; and DALYS as a burden attributable to particular behaviours (17 risk factors) in other diseases.

Cause-specific DALYs correspond to the sum of years lost because of premature death from the specific cause, plus years of life lived with disability in cases affected by the specific cause. DALYs attributable specifically to drug addiction provide a gauge of the "direct" effect of drug consumption on future health loss. Here the opportunity cost of drug-attributable mortality and morbidity is key to the resulting estimate.

DALYs attributable to drug consumption, as an estimate of indirect costs, are obtained from an estimate of attributable burden which measures the incidence of 17 "risk factors" on the final damage (in DALYs). The attributable burden is the reduction that would be observed 
in the actual burden if past levels of exposure had been similar to a given hypothetical distribution (School of Medicine, 2008, p. 79). The risk factor in this case is the use of illicit drugs, which represents by far the least significant risk factor of the 17 examined $(0.0 \%$ of the total, School of Medicine, 2008). The study examines drug consumption as a risk factor in suicide, violence and road traffic accidents, and finds an attributable burden of 417 DALYs. There are sound reasons to suppose that this figure underestimates the burden, mainly because it was calculated using the prevalences reported by the CONACE study for the general population. The CONACE study was based on self-reporting, ${ }^{7}$ which tends to underestimate the magnitude of the phenomenon and leaves out diseases that do not count as etiologic fractions for drugs in Chile, despite having been shown to be linked to drug consumption.

The economic burden in terms of productivity losses estimated as DALYs allows us to attribute a present value to potential future income. Since people value current benefits more highly than future ones, the discount rate applied must significantly influence the amount ultimately discounted. Generally speaking, the more uncertain the future, the higher the value individuals give to the present (Kopp, 2001, p. 19). There is no consensus on the selection of a discount rate (Single and others, 2003; Kopp, 2001) which, in general, "partly reflects the researcher's opinion about how difficult a society will make it to live as a drug user. [...] The lower the selected rate, the higher the estimated social cost" (Kopp, 2001, p. 19). Usually a discount rate of $5 \%$ and $10 \%$ is suggested, however a $3 \%$ rate is most common (Segel, 2006, p. 30).

The study by the School of Medicine of the Catholic University of Chile uses a discount rate of 3\%, which it states corresponds to the long-term investment growth rate and is widely used for evaluating social projects (School of Medicine, 2008, p. 33). This is a relatively low rate, as a result of which the derived costs may be slightly overestimated.

Lastly, the calculation of DALYs with respect to life expectancy for the different cohorts, rather than economically active life, could represent a problem for a cost estimate exercise which assigns a value to income forgone through failure to produce in working life. This difficulty is resolved by including a factor for valuation of the time lived at each age (School of Medicine, 2008, p. 32), in which a greater weighting is given to younger groups.

7 Declaration of an interviewee on whether, for example, he or she has consumed drugs in the past 30 days.

\section{- Procedures for estimating drug-attributable} mortality and morbidity costs (direct and indirect)

The first important decision for estimating costs under this item is the amount to be assigned to each DALY. Here we opt for average income rather than the minimum wage, as in productivity losses from imprisonment, since the 2006 study on drug consumption in the general population in Chile finds that average income reported by drug addicts does not differ significantly from that reported by the rest of the population (and not only are the differences small, but they also favour the addicts). Average autonomous daily income is obtained from the National Socioeconomic Survey (CASEN) of 2006. The direct costs in productivity losses are obtained from the product of drug-addiction-specific DALYs, average autonomous daily income (CLP 11.114 billion in 2006), and 365 (days of the year). This calculation indicates that Chile's productivity losses through mortality and morbidity directly attributable to drug addiction represented an economic burden of CLP 103 billion in 2006.

The same procedure was used for DALYs attributed to drug-related illnesses other than drug addiction (indirect cost). Since DALYs attributable to the risk factor of drug consumption are underestimated, the amount generated by the product of the elements is also underestimated. The economic burden of DALYs attributable to drug consumption as a risk factor for diseases other than addiction was CLP 1.907 billion at current 2006 prices. Overall, the economic burden of mortality and morbidity directly and indirectly attributable to illicit drugs appears to have been around CLP 105 billion (see table 9).

\section{Enforcement}

Drug-attributable enforcement costs -corresponding to the item usually called "law enforcement"- represent the highest proportion of estimated costs in this article (46.6\%). Usually, however, productivity losses represent the highest costs (here, $45.1 \%$ ). There are two main reasons for this difference: one is that Chile has very solid information for calculating this item (especially for adults) and a sound attributable fractions study for calculating indirect costs, which has enabled a comprehensive estimate. By contrast, the etiologic fractions for productivity losses through loss of healthy life years (DALYs as a risk factor) are underestimated.

Calculation of the cost of enforcement for offences directly and indirectly related to drugs usually requires us to define a relevant and ideally equivalent activity on the basis of which to estimate the proportion of drug-linked 


\begin{tabular}{|c|c|c|c|}
\hline & DALYS $^{\mathrm{a}}$ & $\begin{array}{l}\text { Average daily autonomous } \\
\text { income }{ }^{b} \text { in pesos }\end{array}$ & $\begin{array}{l}\text { Cost in millions } \\
\text { of pesos }\end{array}$ \\
\hline DALYs attributable to drug addition, specific cause & 25396 & 11114 & 103022 \\
\hline DALYs attributable illicit drug use, attributable burden (risk factor) & 470 & 11114 & 1907 \\
\hline Total & & & 104929 \\
\hline
\end{tabular}

Source: prepared by the author on the basis of:

a School of medicine, Estudio de carga de enfermedad y carga atribuible 2007, Santiago, Chile, Department of Public Health, Catholic University of Chile, 2008,

b National Socioeconomic Survey (CASEN), 2006.

DALYS: disability adjustment life years.

activities in an institution's total activities. This means assuming that equal resources are allocated to different activities. This assumption is broadly used (Pacula and others, 2009, p. 34), but highly implausible: investigation of a homicide mobilizes far more resources than a petty theft. In order to give each crime a differentiated weighting, a proxy was calculated for the relative difficulty of investigation of different crimes, based on the duration of the judicial processes in each case. As a substitute variable, this does not reflect the difficulty of investigation exactly or proportionally, since all crimes share a threshold level of bureaucratic time and there is always greater possibility in some cases of an alternative, abbreviated procedure or a more vigorous prosecution.

A weighting factor is calculated on the basis of a standardized average trial duration for each type of crime. A factor of less than 1 denotes below-average duration (and difficulty) and a factor of higher than one denotes the reverse. Table 10 shows the values of the weighting factors for crimes in question.

The crimes studied by Valenzuela and Larroulet (2010) are homicide, sexual crimes, violent theft and simple theft, which includes all sorts of non-violent robbery and petty theft. In order to estimate the relative difficulty of simple theft we calculate the weighted average (by frequency) for "non-violent robbery" $(\mathrm{n}=193,517)$ and "petty theft" ( $\mathrm{n}=133,303)$, which gives 87.16 days, or a weighing factor of 0.828 .

With this factor incorporated, we calculated the costs of enforcement for each institution for crimes against the drugs law and related offences. The nominal cost of this item exceeded CLP 126 billion in 2006, with $37.3 \%$ corresponding to direct costs (prosecution, trial and imprisonment for crimes against Act No. 20.000 on drugs and narcotics control), and the remaining $62.7 \%$ corresponding to other types of crimes committed partly as a result of drug consumption, abuse or trafficking (this last item is less frequent: it refers to crimes, such as robbery or homicide, committed in the trafficking of drugs). This means that Chile lost over CLP 47 billion in 2006 in prosecuting drug crimes, and almost CLP 80 billion in enforcement for other types of crime attributable to drug consumption and trafficking. The police system assumed the largest share of these costs (42.6\%), followed by the penitentiary system $(37.1 \%)$ and the judicial system (19\%). Other smaller institutions account for the remaining $1.3 \%$ of enforcement costs: the Medico-Legal Service, the Financial Analysis Unit, the National Customs Service and the Department of Maritime Territory and Merchant Navy (DIRECTEMAR) ${ }^{8}$ (see table 11).

In turn, $14.7 \%$ of these costs (CLP 18.541 billion) are attributable to the prosecution and custody of juveniles for drug offences and other related crimes, while $85.3 \%$ (CLP 107.747 billion) was spent on prosecuting the same crimes in the adult population (see table 12).

\section{(a) Direct enforcement costs: adults}

For adults, the institutions involved in enforcement of drug offences and related crimes are the police, Carabineros de Chile, the detective branch, PDI (the police system), the courts, the Public Prosecutor's Office and the Public Defender's Office (judicial system), the prison guard service, Gendarmería de Chile (which, together with prison-building costs, form the penal system), and other smaller institutions. The combined economic burden for these institutions of prosecuting drug offences was over CLP 40 billion in 2006.

- Carabineros de Chile made 448,128 arrests (INE, 2008b). Of these, 9,870 were for drug offences. The relative difficulty weighting for drug offences

\footnotetext{
8 Information obtained from the study by Olavarría (2009).
} 
Duration of trials and relative difficulty estimate (weighting) of crimes, 2006

\begin{tabular}{|c|c|c|c|}
\hline & Time taken (days) & Standardized value & Weighting factor \\
\hline Theft & 118 & 124.2 & 1.242 \\
\hline Non-violent theft & 99 & 104.2 & 1.042 \\
\hline Petty theft & 70 & 73.7 & 0.737 \\
\hline Homicide & 297 & 312.6 & 3.126 \\
\hline Sexual crimes & 234 & 246.3 & 2.463 \\
\hline Offences against drugs law & 177 & 186.3 & 1.863 \\
\hline General average & 95 & 100 & 1.000 \\
\hline
\end{tabular}

Source: prepared by the author on the basis of information available from the Public Prosecutor's Office, Boletín estadístico. Año 2006, Santiago, Chile, Fiscalía Nacional.

TABLE 11

\author{
Enforcement costs, by enforcement system and direct or indirect relation \\ with consumption, 2006 \\ (Millions of nominal pesos)
}

\begin{tabular}{lcccc}
\hline & Direct & Indirect & Total & Percentage \\
\hline Police system & 22155 & 31650 & 53805 & 42.6 \\
Judicial system & 8248 & 15797 & 24045 & 19.0 \\
Penitentiary and rehabilitation system (SENAME) & 15035 & 31780 & 46815 & 37.1 \\
Others & 1624 & - & 1624 & 1.3 \\
Total & 47062 & 79227 & 126289 & 100 \\
Percentage) & $(37.3)$ & $(62.7)$ & $(100)$ & \\
\hline
\end{tabular}

Source: prepared by the author.

SENAME: National Children's Service.

TABLE 12

Enforcement costs, by enforcement system and prosecution for trafficking and consumption in juveniles and adults, 2006 (Millions of nominal pesos)

\begin{tabular}{lcrr}
\hline & Minors & Adults & Total \\
\hline Police system & 7427 & 46377 & 53805 \\
Judicial system & 199 & 23846 & 24045 \\
Penitentiary and rehabilitation & 10916 & 35900 & 46815 \\
system (sENAME) & & & \\
Others & - & 1624 & 1624 \\
Total & 18541 & 107747 & 126288 \\
(Percentage) & $(14.7)$ & $(85.3)$ & $(100)$ \\
\hline
\end{tabular}

Source: prepared by the author.

SENAME: National Children's Service.

is 1.863 . The product of the percentage of related activities, the weighting factor and the institutional budget shows that in 2006 Carabineros de Chile spent CLP 13.169 billion on prosecuting drug crimes.

- The detective branch, PDI conducted a total of 179,955 investigations in 2006, of which 6,468 related to drugs (INE, 2008a, p. 101). Investigations of drug offences as a proportion of total investigations, multiplied by the weighting factor and the institutional budget, indicate that PDI spent CLP 5.79 billion on investigating drug crimes in 2006.

- In 2006 1,013,833 crimes were registered in the Public Prosecutor's Office, of which 11,323 corresponded to offences against the drugs law. On the basis of the calculation used in the cases above, the Public Prosecutor's Office allocated CLP 1.62 billion to investigating drug offences in 2006.

- The Public Defender's Office took in a total of 212,095 crimes in 2006, of which 8,741 were drug offences. Accordingly, this Office spent CLP 2.281 billion on defending cases of drug crime that year.

- The judicial category includes the courts as well as the Administrative Corporation of the Judicial Branch (CAPJ) and the Judicial Academy. The information on crime for the calculation of costs was taken from the study by Olavarría (2009) who, in turn, used data from an official document prepared by CAPJ; drug offences represented 25,764 of a total of 2,193,142 recorded in the judicial system; the cost associated with drug crimes was CLP 4.253 billion. 
- Gendarmería de Chile registered an average of 3,468 individuals imprisoned for drug offences in 2006 against a total of 38,007 on average that year. This corresponded to $9.13 \%$ of crimes committed by prisoners; this percentage is also assumed to apply to the proportion of resources used for drugrelated imprisonment (no weighting factor is used here, since the effort and resources expended by the prison guard service do not vary by type of crime). Accordingly, in 2006 Gendarmería spent CLP 11.152 billion on drug-related imprisonment.

- The cost of prison-building must be added to the previous calculations. According to the study by Olavarría (2009), the annual cost of prison-building should be measured by yearly depreciation. Olavarría assumes prisons to have a useful life of 50 years, so that prison-building costs for 2006 would be a fiftieth of the cost updated to 2006 of building the prisons in operation that year (Olavarría, 2009, p. 65). By multiplying annual depreciation by the proportion of inmates imprisoned for drug offences, it is found that Chile spent CLP 349 million on prison-building for incarcerating drug offenders. This figure does not coincide with that presented in the Olavarría study, because it counts both drug- and alcohol-related crimes and only prisoners who have been convicted, whereas the present study includes those convicted, on trial or charged for drug (but not alcohol) crime, since they are all held in facilities run by Gendarmería. As always, the estimates correspond to the annual average number of inmates per crime, not the total number of individuals for whom Gendarmería is responsible.

- The drug-attributable costs carried by the MedicoLegal Service are estimated as spending represented on toxicology tests as a percentage of total laboratory tests $(15 \%)$, which in turn represent $61 \%$ of the expenditure incurred by the Service. On this basis, the institution spent CLP 989 million on drug tests in 2006.

- With regard to the Financial Analysis Unit of the Ministry of Finance, which investigates monetary laundering, there is no information on the percentage of suspicious transaction reports which are drugrelated. It was therefore assumed the distribution is similar to that in the Public Prosecutor's Office, which gives an annual expenditure of CLP 132 million on investigating drug-related money laundering crime.

- The National Customs Service spent CLP 344 million on drug-related enforcement in 2006; this figure comes from the budget of the Service's Drugs Control Department.

- The Department of Maritime Territory and Merchant Navy (DIRECTEMAR) engages in a range of activities to investigate and combat drug trafficking; according to the information provided to Olavarría (2009), these represent $0.48 \%$ of the institution's total activities. On this basis, the Department spent CLP 157 million on this item in 2006 (see table 13).

\section{(b) Direct enforcement costs: juveniles}

With regard to juveniles, or under-age offenders, it is estimated that in 2006 Carabineros de Chile, the courts and the National Children's Service (SENAME) together spent CLP 6.822 billion on drug crime enforcement. However, the information for juveniles is imprecise, since before the juvenile penal responsibility act came into effect there were no proper information systems exclusively for under-age offenders.

- There is no precise information on the number of under-age offenders detained for drug-related offences in 2006; however, Carabineros de Chile is known to have detained 25,952 juveniles that year and information is also known on the profiles of law-breaking minors entering the " 24 hours programme" 9 between 2001 and 2005. In order to estimate the number of crimes in 2006, it was assumed that detainments were distributed by crime in the same manner as in 2001-2005. It was thus deduced that 2,396 juveniles were detained in 2006 for drug consumption (the only drug-related crime which is categorized), which represents $0.53 \%$ of all detentions that year. After incorporating the weighting factor, we calculate that the Carabineros de Chile spent CLP 3.196 billion on detaining juveniles for drug consumption in 2006 (see table 14).

- There is a large information gap with respect to juvenile offenders before the juvenile penal responsibility act came into effect in 2007 . There are no public prosecution records for minors aged 14-17 declared competent to stand trial, because in that case they were tried as adults. Nor is there any information on the defence side. It is therefore not possible to estimate the costs for these institutions and only a very rough estimate can be ventured for

\footnotetext{
9 Formally known as the 24-hour integrated safety programme for children and adolescents, the scheme's objective is to compile information on children and teenagers entering the police system and to connect them with the social protection and care network organized around municipalities with the objective of early crime prevention (Allende and Valenzuela, 2008).
} 
Enforcement costs directly attributable to drug trafficking and consumption, adults, 2006

(Millions of nominal pesos)

\begin{tabular}{|c|c|c|c|c|c|c|c|}
\hline & & $\begin{array}{c}\text { Total budget } \\
\text { (millions } \\
\text { of pesos) })^{\mathrm{a}}\end{array}$ & $\begin{array}{l}\text { Related } \\
\text { activities }^{b} \\
\text { (number) }\end{array}$ & $\begin{array}{l}\text { Total } \\
\text { activities }^{\mathrm{b}} \\
\text { (number) }\end{array}$ & $\begin{array}{l}\text { Difficulty } \\
\text { weighting }\end{array}$ & $\begin{array}{l}\text { Proportion } \\
\text { of resources } \\
\text { to drugs }\end{array}$ & $\begin{array}{c}\text { Direct costs } \\
\text { (millions } \\
\text { of pesos) }\end{array}$ \\
\hline Police & Carabineros & 320931 & 9870 & 448128 & 1.863 & 4.10 & 13169 \\
\hline system & PDI & 86469 & 6468 & 179955 & 1.863 & 6.70 & 5790 \\
\hline Judicial & Public Prosecutor's Office & 77878 & 11323 & 1013883 & 1.863 & 2.08 & 1620 \\
\hline system & Public Defender's Office & 29719 & 8741 & 212095 & 1.863 & 7.68 & 2282 \\
\hline \multirow[t]{2}{*}{ Penal system } & GENCHI & 122152 & 12726 & 139333 & - & 9.13 & 11152 \\
\hline & Prison-building ${ }^{c}$ & 3825 & 3468 & 38007 & - & 9.13 & 349 \\
\hline \multirow[t]{4}{*}{ Others } & MLS & & 22757 & & - & & 989 \\
\hline & FAU & 745 & & & - & 17.86 & 133 \\
\hline & Customs & & & & - & & 345 \\
\hline & DIRECTEMAR & 36440 & 16686 & 3878160 & - & 0.48 & 157 \\
\hline
\end{tabular}

Source: prepared by the author on the basis of data from: ${ }^{a} \mathrm{M}$. Olavarría, Estudio nacional sobre costos humanos, sociales y económicos de las drogas en Chile, 2006, Santiago de Chile, Olavarría y Asociados, 2009; Olavarría (2009); ${ }^{\mathrm{b}}$ National Statistical Institute (INE), Anuario de estadísticas policiales. Policía de Investigaciones de Chile, Santiago, Chile, 2008; and Carabineros. Informe anual 2006, Santiago, Chile, 2008; INE (2008a y 2008b Public Prosecutor's Office, Boletín estadístico. Año 2006, Santiago, Chile, Fiscalía Nacional.); Public Prosecutor's Office (undated); Public Defender's Office, Informe estadístico. Año 2006, Santiago, Chile; Public Defender's Office (undated); Poder Judicial, Memoria anual 2006, Santiago, Chile, (2007); Ministry of Justice, Compendio estadístico de la población atendida por Gendarmería de Chile, Santiago, Chile, Gendarmería de Chile, Sub Departamento de Estadística y Control Penitenciario, 2006; ${ }^{\mathrm{c}}$ Annual depreciation.

FAU: Financial Analysis Unit.

MLS: Medico-Legal Service.

DIRECTEMAR: Department of Maritime Territory and Merchant Navy.

TABLE 14

Enforcement costs directly attributable to drug trafficking and consumption, juveniles, 2006

(Millions of nominal pesos)

\begin{tabular}{|c|c|c|c|c|c|c|c|}
\hline & & $\begin{array}{l}\text { Total budget } \\
\text { (millions } \\
\text { of pesos) })^{\mathrm{a}}\end{array}$ & $\begin{array}{l}\text { Related } \\
\text { activities }^{b} \\
\text { (number) }\end{array}$ & $\begin{array}{c}\text { Total } \\
\text { activities }^{\mathrm{b}} \\
\text { (number) }\end{array}$ & $\begin{array}{l}\text { Difficulty } \\
\text { weighting }\end{array}$ & $\begin{array}{l}\text { Proportion } \\
\text { of resources } \\
\text { to drugs }\end{array}$ & $\begin{array}{c}\text { Direct costs } \\
\text { (millions } \\
\text { of pesos) }\end{array}$ \\
\hline Judicial system & Judicial branch & 194337 & 563 & 2193142 & 1.863 & 0.03 & 93 \\
\hline SENAME & & 53042 & 368 & 5524 & 1 & 6.66 & 3534 \\
\hline Total & & & & & & & 6823 \\
\hline
\end{tabular}

Source: prepared by the author on the basis of information from:

SENAME: National Children's Service.

a M. Olavarría, Estudio nacional sobre costos humanos, sociales y económicos de las drogas en Chile, 2006, Santiago, Chile, Olavarría y Asociados, 2009; National Children's Service (SENAME), Informe final de evaluación. Programa de Administración Directa, Santiago, Chile, 2007; Olavarría (2009); SENAME (2007); informal communications from SENAME staff;

b National Institute of Statistics (INE), Carabineros. Informe anual 2006, Santiago, Chile, 2008;INE (2008b Carabineros de Chile/Government of Chile (2007), Programa de Seguridad Integrada para Niños, Niñas y Adolescentes "24 Horas”, Santiago, Chile). 
the court system. Since the number of drug crimes (indeed all crimes) entered in 2006 is not known, an estimate is performed on the basis of trials citing a specific offence as a proportion of completed trials (crimes are not specified for unfinished trials). This gives a drastic underestimation of the resources allocated to judicial procedures, since it yields the conclusion that 503 juveniles entered the courts for drug offence in 2006, which -including the difficulty estimator-would means that only $0.03 \%$ of the institution's resources, i.e. CLP 93 million per year, were spent on investigating juvenile drug crime. This underestimated figure is, however, offset by the magnitude of resources allocated by SENAME, a non-punitive -in principle-institution which also reports to the Ministry of Justice.

- With regard to crime, the role of SENAME consists more of rehabilitation than punishment. However, the Service is responsible for detaining or monitoring juvenile offenders who are imprisoned full or part time. Difficulties surround the estimation of costs for SENAME, too, since although the information on the juveniles in its care is public, reliable budgetary information is lacking for juvenile offenders, since there was no institutional division to this effect before the juvenile penal responsibility act. The budget information used is a reconstruction of different pieces of information provided by SENAME officials and the information submitted by SENAME for the final report on the direct administration programme
(SENAME, 2007). On this basis, we estimate that in 2006 SENAME spent CLP 3.534 billion on juveniles who committed drug-related crimes (see table 14).

\section{(c) Indirect enforcement costs: adults}

As noted earlier, one of the soundest aspects of this article is the estimate of indirect costs of drug enforcement based on the recent paper on attributable fractions by Valenzuela and Larroulet (2010) and on detailed information on drug-related crime from the various institutions involved.

As may be surmised from table 15, in 2006 the main institutions involved in prosecuting crime in Chile spent CLP 67.508 billion on enforcement for crimes committed by individuals over age 18 because of drugs, whether to obtain it (in the case of addicts), under its influence (when the crime would not have been committed otherwise) or in the drug market, following Goldstein's tripartite model.

The institutions spending the most on related crimes were Gendarmería (CLP 23.658 billion) and Carabineros de Chile (CLP 17.194 billion). They are followed by PDI (CLP 10.225 billion) and the Public Prosecutor's Office (CLP 9.403 billion). If these amounts are broken down by crime, simple theft is by far the most common crime committed because of drugs. It costs the institutions involved CLP 47.841 billion, i.e. $71 \%$ of costs for drugrelated crime. Following at a considerable distance are violent theft (CLP 16.184 billion), sexual crime (CLP 2.142 billion) and homicide (CLP 1.341 billion).

\section{Enforcement costs indirectly attributable to drug trafficking and consumption, adults, by type of crime, 2006 \\ (Millions of nominal pesos)}

\begin{tabular}{llccrrr}
\hline & & Simple theft & Violent theft & Sexual crimes & Homicides & Total \\
\hline \multirow{2}{*}{ Judicial system } & Public Prosecutor's Office & 6874 & 2276 & 227 & 26 & 9403 \\
& Public Defender's Office & 1859 & 731 & 87 & 59 & 2736 \\
& Courts & 2414 & 949 & 113 & 77 & 3552 \\
\hline Police system & Carabineros & 14637 & 2353 & 120 & 83 & 17194 \\
& PDI & 6239 & 2354 & 1217 & 316 & 10225 \\
\hline \multirow{2}{*}{ Penal system } & Gendarmería & 15338 & 7292 & 367 & 660 & 23658 \\
& Prison-building & 480 & 228 & 12 & 741 \\
\hline \multirow{2}{*}{ Total } & & 47841 & 16184 & 2142 & 1341 & 67508 \\
\hline
\end{tabular}

Source: prepared by the author on the basis of information from M. Olavarría, Estudio nacional sobre costos humanos, sociales y económicos de las drogas en Chile, 2006, Santiago, Chile, Olavarría y Asociados, 2009; National Institute of Statistics (INE), Anuario de estadísticas policiales. Policía de Investigaciones de Chile, Santiago, Chile, 2008; and Carabineros. Informe anual 2006, Santiago, Chile, 2008; Public Prosecutor's Office, Boletín estadístico. Año 2006, Santiago, Chile, Fiscalía Nacional.); Public Defender's Office, Informe estadístico. Año 2006, Santiago, Chile; Poder Judicial, Memoria anual 2006, Santiago, Chile, 2007; Public Prosecutor's Office, Compendio estadístico de la población atendida por Gendarmería de Chile, Santiago, Chile, Gendarmería de Chile, Sub Departamento de Estadística y Control Penitenciario, 2006; and E. Valenzuela y P. Larroulet, "La relación droga y delito: una estimación de la fracción atribuible", Estudios públicos, $\mathrm{N}^{\circ} 119$, Santiago, Chile, Centro de Estudios Públicos, 2010. 
The calculation is the same as that used for the section on direct costs, except that in this case it includes attributable fractions.

\section{(d) Indirect enforcement costs: juveniles}

The estimation of indirect costs for juveniles uses the same strategies as those described for estimating the direct costs for this group, owing to gaps in the information available. Again, therefore, the cost of justice is heavily underestimated. The calculation applies an attributable fraction factor for each crime, which is specific to the juvenile population (Valenzuela and Larroulet, 2010).

Together, the institutions involved spent CLP 11.719 billion on enforcement for drug-related crimes. The institution with the heaviest costs in this area was SENAME, with CLP 7.382 billion, followed by Carabineros de Chile, with CLP 4.231 billion and the judicial system with CLP 106 million, though this is a drastic underestimate.

By crime, simple theft is again the crime that imposes the highest costs on the enforcement system (CLP 6.362 billion, or 54\%), although the lead is far shorter than is the case with adults. This is followed quite closely by drug-related theft with violence and intimidation (CLP 5.245 billion, or 45\%), and at a greater distance by homicide (CLP 73 million) and sexual crime (CLP 38 million), which are statistically insignificant in this population (a combined $1 \%$ between the two) (see table 16).

TABLE 16

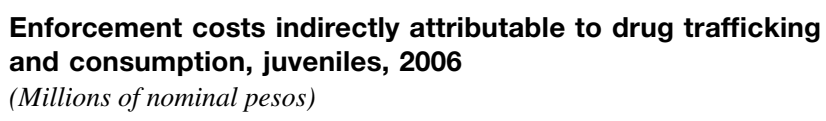

Enforcement costs indirectly attributable to drug trafficking and consumption, juveniles, 2006

(Millions of nominal pesos)

\begin{tabular}{|c|c|c|c|c|c|c|}
\hline & & $\begin{array}{l}\text { Socioeconomic } \\
\text { cost, simple } \\
\text { theft }\end{array}$ & $\begin{array}{l}\text { Socioeconomic } \\
\text { cost, violent } \\
\text { theft }\end{array}$ & $\begin{array}{l}\text { Socioeconomic } \\
\text { cost, sexual } \\
\text { crime }\end{array}$ & $\begin{array}{l}\text { Socioeconomic } \\
\text { cost, } \\
\text { homicides }\end{array}$ & $\begin{array}{c}\text { Cost indirectly } \\
\text { attributable to } \\
\text { PAS }^{\mathrm{a}}\end{array}$ \\
\hline Judicial system & Courts & 44 & 62 & 0.378 & 0.165 & 106 \\
\hline Police system & Carabineros & 1952 & 2279 & - & - & 4231 \\
\hline SENAME & & 4366 & 2904 & 38 & 73 & 7382 \\
\hline Total & & 6362 & 5245 & 38 & 73 & 11719 \\
\hline
\end{tabular}

Source: prepared by the author on the basis of information from Poder Judicial, Memoria anual 2006, Santiago, Chile, 2007; Carabineros de Chile/Government of Chile (2007), Programa de Seguridad Integrada para Niños, Niñas y Adolescentes "24 Horas", Santiago, Chile; National Institute of Statistics (INE, 2008b), Carabineros. Informe anual 2006, Santiago, Chile.

a Psycho-active substances.

\section{IV}

\section{Conclusions}

This article has attempted to demonstrate that the economic burden of drug consumption and trafficking in Chile in 2006 was at least CLP 266.744 billion in current prices that year, or CLP 207.531 billion in today's terms (30 April 2011). Much of that sum reflects productivity losses and enforcement costs, be it for drug offences directly or other crimes committed because of drugs. The losses directly attributable to drug consumption and trafficking are estimated at CLP 173.708 billion, and the indirect costs are estimated at CLP 93.036 billion (see table 17).

These results were obtained using the COI approach to evaluate the impacts of drug consumption and trafficking on society as a whole. This indictor of "negative
TABLE 17

Total costs by item, direct and indirect, 2006 (Millions of nominal pesos)

\begin{tabular}{lrrr}
\hline & Direct & Indirect & Total \\
\hline $\begin{array}{l}\text { Prevention } \\
\text { Public health }\end{array}$ & 13070 & & 13070 \\
$\begin{array}{l}\text { Productivity losses } \\
\text { Enforcement (adults } \\
\text { and juveniles) }\end{array}$ & 108484 & 13810 & 122293 \\
$\begin{array}{l}\text { Total } \\
\text { Total adjusted to 30 }\end{array}$ & 47062 & 79227 & 126288 \\
April 2011 & 173708 & 93036 & 266744 \\
\hline
\end{tabular}

Source: prepared by the author. 
externality" may serve as a basis for decision-making and for gauging the effectiveness of programmes and public policies aimed at reducing drug consumption and trafficking and its harmful effects on society at large. A study of this sort also brings to light information which is not usually available to researchers and the general public, either because it is not published or because the various institutions categorize it in different ways.

The estimates given have failings which have been amply described. Insofar as they reflect information gaps, they highlight the need for specific studies in Chile to produce more accurate estimates that can quantify the problem more realistically. The main requirements in this regard are as follows:

(i) Ideally, all State institutions should provide accurate and detailed information. This is particularly urgent in the case of the public health system, the judicial system and the prison guard service. The public health system should separate drug- and alcohol-related items in their reported budgets and make budgetary information available not only in reference to hospital care, but also for primary care, especially as regards the cost of treating drugrelated diseases other than addiction. It would also be desirable to produce unified records for care and treatment in the private health system, in order to quantify the treatment given for addiction and other drug-related illnesses. The judicial system should provide more detailed information on its actions and respective budget, and Gendarmería should produce a clear record of crimes by judicial status, and a reliable profile of the individuals imprisoned by type of crime.

(ii) A comprehensive register of ngos involved in work on illicit drugs in Chile would be highly useful, distinguishing autonomous budget fractions from government contributions.

(iii) Chile should encourage the development of attributable fractions studies to help determine the degree of relation between drug consumption and related behaviours or consequences, especially in the field of health. Work in Australia, Canada and the United States has shown that such studies provide extremely valuable information for public policy interventions, with a view to targeting interventions and resources on substances that generate the most adverse impacts in aggregate terms.

(iv) More generally, Chile needs studies of this sort with unified criteria in order to evaluate the costs of tobacco and alcohol consumption, in order to compare their consequences and target and integrate interventions. A unified methodology, as in Australia and Canada, would enable comparison of the harmful effects of each substance and provide grounds for decisions on channelling prevention and rehabilitation resources. Although government agencies responsible for illegal drug matters afford great importance to drug consumption and its potential effects, these studies offer a means of assessing the burden that each drug represents for society in a more objective, substantiated manner. There is no reason, a priori, to assume that illegal drug prevention and rehabilitation merit more attention than legal drugs. It is possible that in Chile, for example, just as programmes tackle illegal drugs such as cocaine base paste, they should more broadly tackle alcohol, which is taxed less than tobacco and is allowed to be advertised, despite the fact that alcohol both directly and indirectly generates multiple forms of violence and a higher cost in dalys than tobacco.

The steps suggested would enable Chile to develop high-quality instruments for measuring the scale of problems associated with drug consumption and trafficking and for setting a solid baseline to support analysis of the costs and benefits of public policy interventions in this field.

(Original: Spanish) 


\section{Bibliography}

Allende, C. and E. Valenzuela (2008), "Programa 24 horas: Evaluación de una estrategia", Camino al Bicentenario. Propuestas para Chile, I. Irarrázabal and M. Morandé, Santiago, Chile, Catholic University of Chile.

Budgetary Affairs Bureau (2007), Informe final de evaluación. Programa de Administración Directa, Santiago, Chile, Ministry of Justice, National Children's Service.

Carabineros de Chile/Government of Chile (2007), Programa de Seguridad Integrada para Niños, Niñas y Adolescentes "24 Horas", Santiago, Chile.

CICAD (Inter-American Drug Abuse Control Commission) (2006), Pautas metodológicas para estudios de impacto económico del abuso en el consumo de sustancias psicoactivas, Washington, D.C., Organization of American States (OAS).

Collins, D.J. and H.M. Lapsley (2008), The Costs of Tobacco, Alcohol and Illicit Drug Abuse to Australian Society in 2004/05, Canberra, Commonwealth of Australia.

Conace (National Drug Control Council) (2007), Segundo estudio nacional de drogas en población penal, Santiago, Chile.

(2006), Séptimo estudio nacional de drogas en población general de Chile, Santiago, Chile.

(2005), Estudio de costos asociados al consumo y tráfico de spa ilegales en Chile para el año 2003, Santiago, Chile.

CONACE/CIGES (National Drug Control Council/Centro de Capacitación, Investigación y Gestión para la Salud Basada en Evidencia) (2001), Estudio de consumo de drogas en consultantes de los servicios de urgencia, Santiago, Chile.

Defensoría Penal Pública (n/d), Informe estadístico. Año 2006, Santiago, Chile.

Escuela de Medicina (2008), Estudio de carga de enfermedad y carga atribuible 2007, Santiago, Chile, Departamento de Salud Pública, Catholic University of Chile.

García-Altés, A., J.M. Ollé and J. Colom (2002), "The social cost of illegal drug consumption in Spain", Addiction, vol. 97, No. 9.

Godfrey, C. and others (2002), "The economic and social costs of class A drug use in England and Wales, 2000", Home Office Research Study, No. 249, London, Home Office.

Goldstein, P. (1985), "The drugs/violence nexus. A tripartite conceptual framework", Journal of Drug Issues, vol. 39.

INE (National Institute of Statistics) (2008a), Anuario de estadísticas policiales. Policía de Investigaciones de Chile, Santiago, Chile. (2008b), Carabineros. Informe anual 2006, Santiago, Chile.

Kopp, P. (2001), Calculating the Social Cost of Illicit Drugs. Methods and Tools for Estimating the Social Cost of the Use of Psychotropic Substances, Strasbourg, Council of Europe.

Kopp, P. and F. Philippe (2006), Le coût social des drogues en 2003: les dépenses publiques dans le cadre de la lutte contre les drogues en France en 2003, Paris, Observatoire français des drogues et des toxicomanies.
Longo, M.C. and others (2000a), "The prevalence of alcohol, cannabinoids, benzodiazepines and stimulants amongst injured drivers and their role in driver culpability. Part I: The prevalence of drug use in drivers, and characteristics of the drug-positive group", Accident Analysis and Prevention, vol. 32, Amsterdam, Elsevier.

(2000b), "The prevalence of alcohol, cannabinoids, benzodiazepines and stimulants amongst injured drivers and their role in driver culpability. Part II: The relationship between drug prevalence and drug concentration, and driver culpability", Accident Analysis and Prevention, vol. 32, Amsterdam, Elsevier.

Ministry of Justice (2006), Compendio estadístico de la población atendida por Gendarmería de Chile, Santiago, Chile, Gendarmería de Chile.

Ministerio Público (s/f), Boletín estadístico. Año 2006, Santiago, Chile, Fiscalía Nacional.

OEA/CICAD (Organization of American States/Inter-American Drug Abuse Control Commission) (2006), Estudio de costos humanos, sociales y económicos de las drogas.

Office of National Drug Control Policy (2004), The Economic Costs of Drug Abuse in the United States, 1992-2002, Washington, D.C., Executive Office of the President.

Olavarría, M. (2009), Estudio nacional sobre costos humanos, sociales y económicos de las drogas en Chile, 2006, Santiago, Chile, Olavarría y Asociados.

Pacula, R.L. and others (2009), Issues in Estimating the Economic Cost of Drug Abuse in Consumming Nations, RAND Corporation [online] http://www.rand.org/pubs/technical_reports/ TR709.html.

Poder Judicial (2007), Memoria anual 2006, Santiago, Chile.

Rehm, J. and others (2006), The Costs of Substance Abuse in Canada 2002, Ottawa, Canadian Centre on Substance Abuse.

Ridolfo, B. and C. Stevenson (2001), The Quantification of Drugcaused Mortality and Morbidity in Australia, 1998, Canberra, Australian Institute of Health and Welfare.

Segel, J.E. (2006), Cost-of-Illness Studies-A Primer, RTI International. SENAME (National Children's Service) (2007), Informe final de evaluación. Programa de Administración Directa, Santiago, Chile, Ministry of Justice.

(2006), Estudio de prevalencias de consumo y factores asociados en población infractora adolescente, Santiago, Chile, Institute of Sociology, Catholic University of Chile.

Single, E. and others (2003), International Guidelines for Estimating the Costs of Substance Abuse, Washington, D.C., World Health Organization.

Valenzuela, E. and P. Larroulet (2010), "La relación droga y delito: una estimación de la fracción atribuible", Estudios públicos, No. 119, Santiago, Chile, Centre for Public Studies. 